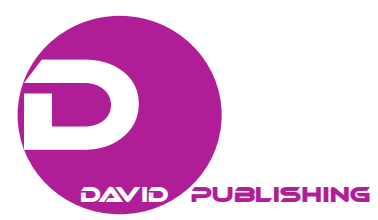

\title{
Why Brazilian Women Are Not on Top: The Work-Life Reconciliation Hypothesis
}

\author{
Marcia Cristina Esteves Agostinho \\ University Estácio de Sá, Rio de Janeiro, Brazil
}

\begin{abstract}
The female presence in middle management is already significant in Brazil. Yet, women hold only 7\% of the board seats. Why are there so few women in corporative top ranks? Is it possible that prejudice and sexism work selectively, allowing women to ascend not beyond a certain point in corporate hierarchy? This paper rejects such a perspective and aims at understanding the dynamics that drive women against the executive suite. The premise beneath this research is that women are not victims, but autonomous individuals. In order to test the hypothesis of Brazilian women choosing not to ascend, the first step was to analyze Brazilian Institute of Geography and Statistics' (IBGE) data on work force and employment. Thereafter, the research explores the possibility that organizational dynamics is a major factor for women to deal with work-life issues. Studies of scientific organizations show that flexibility helps conciliate work and life. The conclusion is: if corporations could emulate the scientific organizational environment, probably they would not only attract more women to the executive suite, but also adapt to a transforming society.
\end{abstract}

Keywords: women, top-management, work-life balance, work organization

\section{Introduction}

The board of directors has been, in most cases, a male-exclusive space. In Brazil, it is not different. Women hold only 7\% of the board seats of Brazilian companies (IBGC, 2011). The number, however, is not so low if compared with other countries. Although in Norway and Sweden women occupy more than one third of the positions on the highest levels, in many developed countries, the number of women at the top of the corporations ranges between 1\% (Japan) and 15\% (US).

The fact that it is rare to find women in top management positions has often been treated with sexist bias. Some authors argue that the lack of opportunities results from the old prejudice that pushes women towards so-called female occupations (Thiry-Cherques, 2003). According to this point of view, those occupations are not so well regarded as male ones and, therefore, their salaries - for women and men alike-are lower than salaries of typical male occupations. Others defend regulations that oblige organisations to promote a certain number of women to high positions as a way to compensate them for a social injustice. In any case, those arguments imply that women are victims or, at least, passive individuals.

Since the 1980's, literature has presented several arguments in favour of gender diversity among board

Marcia Cristina Esteves Agostinho, D.Sc., professor of Production Engineering, Barra da Tijuca, University Estacio de Sa, Rio de Janeiro, Brazil.

Correspondence concerning this article should be addressed to Marcia Cristina Esteves Agostinho, Rua General Venancio Flores, 371/ap.401, Leblon, RJ-CEP 22441-090, Rio de Janeiro, Brazil. 
members (N. Smith, V. Smith, \& M. Verner, 2006). Moreover, women have been proving their competence in many fields and the job market already recognizes their superior educational background. The female presence in middle management is already significant. Hence, why are there so few women (Brazilian, in particular) in corporate top ranks? Is it possible that prejudice and sexism work selectively, allowing women to ascend not beyond a certain point in the corporate hierarchy where their leadership is useful, but not too powerful to threat men on board?

This paper rejects such a perspective and aims at understanding the dynamics that drive women against the executive suite. The premise beneath this research is that women are not victims, but autonomous individuals capable of acting in accordance to their judgement. Therefore, the focus is on aspects that distinguish middle management from the highest positions and could make an eventual uprising less attractive for them.

\section{Methodology}

In order to test the hypothesis of Brazilian women choosing not to ascend, the first step was to analyze Brazilian Institute of Geography and Statistics' (IBGE) data on work force and employment. Then, it was possible to identify women's behaviour regarding education, occupations, and turnover.

As turnover is a key-concept for the issue of career progress, the next step was to research the international literature, focusing on female turnover-mainly in top management. The results pointed to a relation between female turnover and work-life balance, suggesting that it tends to be higher than male turnover. Considering that such results may imply some cultural bias, it was decided to prioritize research papers from countries culturally similar to Brazil.

Thereafter, a study conducted in Portugal (Brandão, 2013) became an important reference to the present research. Investigating work in a scientific institute in Lisbon, the author did not observe any difference concerning female or male turnover. Such atypical findings provided the insight-explored here-that organizational dynamics is a major element for women to deal with work-life issues.

Previous researches on how scientific laboratories (Latour \& Woolgar, 1986) and science-based companies (Agostinho, 1994) are operated and suggest a remarkable difference between knowledge-based institutions and business corporations. Such differences in organizational cultural result in different workplace rules, which tend to be more favorable to flexible work arrangements. This would explain why many talented female managers quit their jobs in big promising corporations, changing to nonprofits agencies and educational institutions, or even risk themselves as self-employed.

This insight guided the interpretation of statistic data and the discussion of results.

\section{Women at Work}

More educated and in charge of their fertility control, women started with a strong participation in the labour market in the 21st century.

It is worth noting how intimate decisions—as having children—reflect upon aggregate numbers. In 1950, women had six children on average and they represented only $14.7 \%$ of the economically active population (Agostinho \& Lopes, 2014). In 2009, however, the fertility rate in Brazil had already fallen to 1.94 children per woman, when women participation reached $44 \%$ of the economically active people. Yet, more than half of the economically active population (56\%) is still male (IBGE, n.d.a). 
It is important to consider the absolute numbers. As shown on Table 1, the quantity of women old enough to work is higher than the quantity of men with the same age. However, only half of them are willing to look for work. On the other hand, 72\% of men are encouraged to find a job. It means that, in Brazil 2014, there are only 43 million women available for work, for any reason. It is worth stressing that, at the same time, 56 million men compete for a position in the job market.

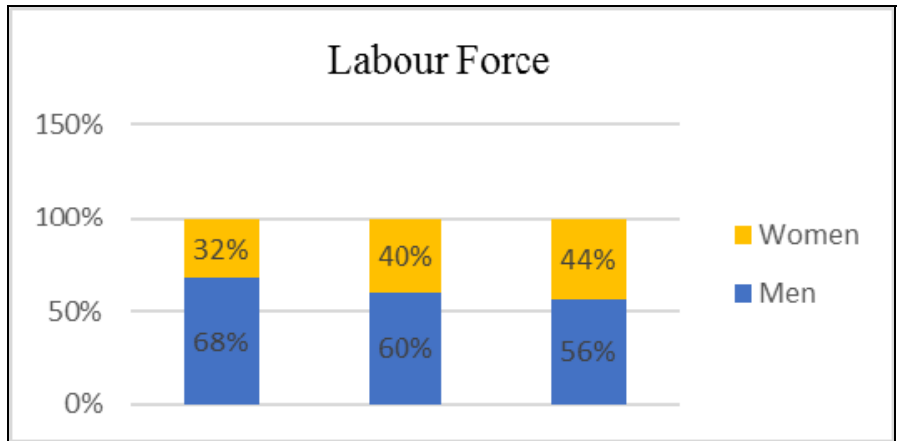

Figure 1. Economically active population in Brazil-years of 1991, 2000, and 2010.

Table 1

People Available for Work

\begin{tabular}{llll}
\hline Sex & $\begin{array}{l}\text { Working-age population } \\
\text { (million) }\end{array}$ & $\begin{array}{l}\text { People in the labor force } \\
\text { (million) }\end{array}$ & $\begin{array}{l}\text { People in work } \\
\text { (million) }\end{array}$ \\
\hline Total & 163.151 & 99.326 & 92.875 \\
Men & 77.670 & 56.091 & 52.977 \\
Women & 85.480 & 43.235 & 39.897 \\
\hline
\end{tabular}

Source: IBGE-PNAD Oct-Dec 2014.

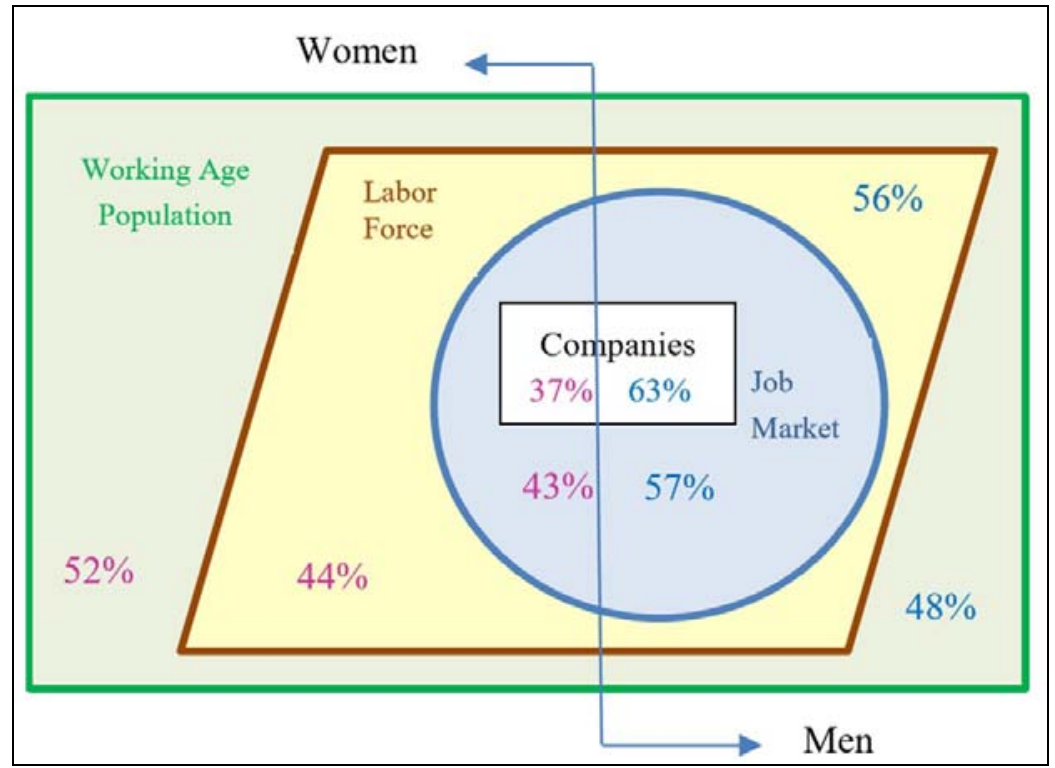

Figure 2. Proportion of men and women in the job market-Brazil Oct-Dec 2014.

Considering the numbers represented on Figure 2, nowadays, the proportion of women and men who are in work is approximately the same as those in the labour force (43\%/44\% for women and 57\%/56\% for men). Therefore, it seems unlikely that job market expresses any prejudice or restrictions against female workers. 
Furthermore, Figure 2 also shows that the jobs held in companies are not a reality for most of working women. In that particular environment, 63\% of employees are men. Although there are almost 40 million working women in Brazil, just 12 million of them work in companies (IBGE, n.d.b). In other words, 70\% of such women have a different employment status.

Regarding the status of employment, Table 2 reveals important differences between female and male decision-making.

Table 2

Employment Status

\begin{tabular}{lll}
\hline & Women \% & Men \% \\
\hline Employed with contract & $44 \%$ & $46 \%$ \\
Employed without contract & $23 \%$ & $18 \%$ \\
Self-employed & $17 \%$ & $25 \%$ \\
Civil service (including military) & $7 \%$ & $4 \%$ \\
Subsistence worker & $4 \%$ & $4 \%$ \\
Unpaid worker & $3 \%$ & $1 \%$ \\
Employers & $2 \%$ & $2 \%$ \\
\hline
\end{tabular}

Source: IBGE (n.d.c). SIDRA, table 3461.

Such statistics show that many women prefer civil service (7\%) to a corporate career. The fact that only $4 \%$ of men go to civil service (including military) may suggest that women seek greater flexibility, but with less risk. However, women's aversion to risk is not so high, since $23 \%$ of women (against $18 \%$ of men) accept jobs without a contract. Thus, when they have to choose between flexibility and labour rights, women seem to stay with the first. The importance of flexible hours can also explain why so many women decide to work independently, as self-employed $(17 \%)$ or employers $(2 \%)$. But these numbers expose another important female trait: altruism. Unpaid work is three times more prevalent among women than among men, showing that female activity cannot be fully understood by the logic which governs corporate career success.

\section{A Matter of Availability}

Traditionally, women are in charge of family issues. Until some decades ago, maternity was seen as the reason why women could not dedicate her time to work as much as men do. However, the recent fall of fertility rate has not changed the protagonist role women play in the family. Even though many women have decided not to have any children, they have not given up on marriage. According to Brazilian official data (Agostinho, 2013), from 2003 to 2010, the number of marriages rose more than 30\%. It means that, even if they are not mothers so frequently as before, they continue to be wives.

The pattern of female working hours reflects women's duties and joys. It differs greatly from men's - although, like women, less than half men work the "typical" 40 or 44 hours per week. It should not be surprising that more than $1 / 3$ of women work less than 40 hours per week. Probably, they would be more if $52 \%$ of women over 60 years of age had also formal jobs in which 40 hours' work is compulsory. In an environment of low flexibility as the Brazilian labour market, the oldest might be taking charge of the care of the houses and the children of the $23 \%$ of younger women who dedicate more than 44 hours to work each week. 
In 2010, nearly 8 million women worked more than 44 hours weekly (22\% of women in work). On the other hand, more than 16 million men were willing to dedicate much of their time to work (33\% of men in work). Therefore, there were twice as many men to take the top corporate positions.

In purely quantitative terms, this would be a reason for more men than women working in time-demanding jobs. After all, men are, at least, more available. Thus, what should be surprising is to see management positions equally distributed between men and women. Certainly, the level of education and the skills profile has favored women in this competition.

Table 3

Working Hours per Age and Sex

\begin{tabular}{llllllll}
\hline \multirow{2}{*}{ Sex } & $\begin{array}{l}\text { Hours } \\
\text { per week }\end{array}$ & $\begin{array}{l}\text { Less than } 29 \\
\text { years old }\end{array}$ & \multirow{2}{*}{30 to 39} & \multirow{2}{*}{40 to 49} & \multirow{2}{*}{50 to 59} & $\begin{array}{l}\text { More than } 60 \\
\text { years old }\end{array}$ & All ages \\
\hline \multirow{3}{*}{ Men } & Less than 40 & $23 \%$ & $16 \%$ & $16 \%$ & $19 \%$ & $32 \%$ & $20 \%$ \\
& 40 to 44 & $47 \%$ & $49 \%$ & $48 \%$ & $47 \%$ & $41 \%$ & $47 \%$ \\
\multirow{3}{*}{ Women } & More than 44 & $30 \%$ & $35 \%$ & $36 \%$ & $34 \%$ & $27 \%$ & $33 \%$ \\
& Less than 40 & $35 \%$ & $31 \%$ & $33 \%$ & $38 \%$ & $52 \%$ & $35 \%$ \\
& 40 to 44 & $44 \%$ & $46 \%$ & $44 \%$ & $41 \%$ & $31 \%$ & $43 \%$ \\
\hline
\end{tabular}

Source: IBGE (n.d.d). SIDRA, table 3582.

\section{The Work-Life Reconciliation Hypothesis}

If the focus of this research is on the kind of women that could be in the highest corporate ranks, it is useful to investigate work-life issues among women of the intellectual elite. After all, education has been considered as the main drive to professional ascension. Thus, scientists in both universities and research institutes become an excellent subject.

Two studies help interpret our findings and answer why Brazilian women are not on top: (1) academic scientists working with nine universities in the US (Fox, Fonseca, \& Bao, 2011); (2) research scientists working in a technological institute in Portugal (Brandão, 2013). According to the American study, the fact of being married or having children under age six years increases the probability of work to family conflict only among men, not among women. The authors suggest that women scientists with children are highly selective in a way and they devote time to related activities.

It is worth noting that being "highly selective" implies that those women have the power to decide when and where to perform their work. In other words, they have autonomy to manage their time, establishing priorities according to the changing demands of work and family.

Although scientists are also used to work extensive hours, it does not seem to cause a major impact on personal life. Brandão (2013) notes that "it is interesting to note that, despite the scientists/researchers of ITQB work 55 hours (...), they do not feel intensely the impact of work on his personal life” (p. 35). She explains it with the fact that scientists have flexibility. They can leave the laboratory solving urgent family problems and go on with their work afterwards.

Both these studies show the importance of autonomy and flexibility to manage work and family affairs. Contrary to university and scientific-based institutions, such things are not common in most companies. Even among top executives, a certain kind of "ethics of work" prevails, forcing people-men and women—to prioritize work over family. 
The results presented here suggest that Brazilian women might be choosing not to ascend to the highest positions in order to better balance their professional and personal lives. Moreover, the interactions between men and women, both publically and privately, are becoming more symmetrical. In such context, it is reasonable to consider that male and female expectations will converge to the point of making corporations review their modes of organizing work towards alternatives that provide autonomy and flexibility.

Elsewhere (Agostinho, 2003; Agostinho \& Teixeira de Castro, 2003), we developed an organisational framework whose fundamental aspect is autonomy. The "Autonomous Management System" was designed to support teamwork and open communication, incorporating principles of network in the formal structure. Besides producing superior performance, this self-organizing management is able to help reconciliate the spheres of work and family which have being in conflict for so long.

\section{Conclusion}

Since the beginning of the last century, the impact of social and psychological factors on work has been evident. The entry of women in the labour market enriched the discussion and provided new insights on motivation and work organisation. It also gave evidence to the conflict of work and family. The central argument in this paper is that such a conflict is the main reason why so many women choose not to engage in top management jobs, mainly in the board of directors.

The scientific jobs have rules and dynamics that function as if workers are presumed to be mature professional adults, who are able to assume their responsibilities. The corporate jobs, which, in a certain sense, descend from industrial proletariat, are not used to rely on the capacity of judgement of the workers. If corporations could emulate the scientific organisational environment, probably they would attract more women to the executive suite and better adapt to a transforming society.

\section{References}

Agostinho, M. (1994). Da Bancada para o Balcão: Como cientistas conduzem seus negócios. (Master dissertation, COPPE/UFRJ, 1994).

Agostinho, M. (2003). Complexidade e organizações: Em busca da gestão autônoma. São Paulo: Editora Atlas.

Agostinho, M. (2013). Vínculos: Sexo e amor na evolução do casamento. Rio de Janeiro, Odisseia.

Agostinho, M., \& Lopes, A. (2014). Reprodução e Produção Reflexiva: Números de um Brasil menos fecundo. Revista Aquila, (10), 55-67.

Agostinho, M. E., \& Teixeira de Castro, G. (2003). Co-creating a self-organizing management system: A Brazilian experience. In Complexity, Ethics and Creativity Conference. London School of Economics. Retrieved from http://www.researchgate.net/publication/237675945_CO-CREATING_A_SELF-ORGANIZING_MANAGEMENT_SYSTE M_A_BRAZILIAN_EXPERIENCE

Brandão, D. P. (2013). Conflito trabalho-família e intenções de turnover na profissão de cientista em Portugal: O caso do ITQB. Instituto Superior de Economia e Gestão. Retrieved from http://hdl.handle.net/10400.5/6184

Fox, M. F., Fonseca, C., \& Bao, J. (2011). Work and family conflict in academic science: Patterns and predictors among women and men in research universities. Social Studies of Science, 41(5), 715-735.

IBGC. (2011). Relatório de mulheres na Administração de Empresas Listadas. Retrieved from http://www.ibgc.org.br/userfiles/files/Mulheres_no_Conselho.pdf

IBGE. (2010). Censo Demográfico. Retrieved from http://www.ibge.gov.br/home

IBGE. (n.d.a). $\quad$ SIDRA, table $616 . \quad$ [Data http://www.sidra.ibge.gov.br/bda/tabela/protabl.asp?c=616\&z $=\mathrm{cd} \& \mathrm{o}=2 \& \mathrm{i}=\mathrm{P}$

IBGE. (n.d.b). SIDRA, table 2718 [Data http://www.sidra.ibge.gov.br/bda/tabela/protabl.asp?c=2718\&z=p\&o=5\&i=P 
IBGE. $\quad$ (n.d.c). $\quad$ SIDRA, table $3461 \quad$ [Data $\quad$ file]. $\quad$ Retrieved from http://www.sidra.ibge.gov.br/bda/tabela/protabl.asp?c=3461\&z=cd\&o=13\&i=P

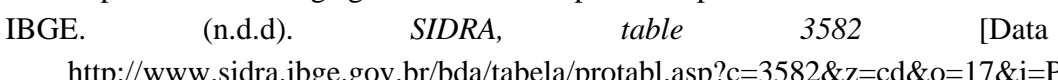

our, B., \& Woolgar, S. (1986). Laboratory life: The construction of scientific facts. Princeton: Princeton University Press.

Smith, N., Smith, V., \& Verner, M. (2006). Do women in top management affect firm performance? A panel study of 2,500 Danish firms. International Journal of Productivity and Performance Management, 55(7), 569-593.

Thiry-Cherques, H. R. (2003). Condição feminina e percepção dos valores morais no nível gerencial e técnico das organizações brasileiras. Revista de Administração Publica, 477-511. 